Charles Møller, Pernille Kræmmergaard \& Pall Rikhardsson

The Emergence of Enterprise Systems Management

- A Challenge to the IS Curriculum

Informatics

Research Group 


\title{
The Emergence of Enterprise Systems Management - A Challenge to the IS Curriculum
}

Charles Møller, $\mathrm{PhD}$

Associate Professor

Informatics Research Group

Aarhus School of Business

charles@asb.dk

Pernille Kræmmergaard, PhD

Associate Professor

Informatics Research Group

Aarhus School of Business

pkj@asb.dk

Pall Rikhardsson, $\mathrm{PhD}$

Associate Professor

Management Accounting Research Group

Aarhus School of Business

par@asb.dk

\begin{abstract}
This paper proposes four cornerstones of a future Information Systems curriculum. It analyzes the challenges of the IS curriculum based on the development of enterprise systems, and further argues that the practice and the research into enterprise systems have progressed to a new stage resulting in the emergence of Enterprise Systems Management (ESM). Enterprise Systems Management calls for new competences and consequently represents new challenges to the IS curriculum. The paper outlines potential teaching issues and discusses the impact on the IS curriculum. Finally the paper suggests ways of approaching the challenges.
\end{abstract}

\section{Introduction}

Today virtually every major business has implemented one or more ERP systems or simpler enterprise systems (ES). A recent study in Denmark revealed that more that 75 per cent of the 500 largest enterprises had implemented one or more ES. The average age of the ES in the survey was 2.8 years, and we conclude that management and organization of ES projects and upgrades is to be considered a permanent part of 
any business. Moreover, innovative use of ES is to be considered in any business context (Møller, Kræmmergaard \& Rotbøl, 2003).

The concept of ES is best explained through the evolution of ERP (Wortmann, 1998; Klaus, Rosemann \& Gable, 2000; Markus \& Tanis, 2000). The concept of ES has evolved over almost fifty years driven by changing business requirements, new technologies and software vendors' development capabilities. In recent years ES have developed tremendously, and ERP systems have evolved into ERP II (Møller, 2004).

This paper will argue that we are facing a new practice - what we call Enterprise Systems Management (ESM). ESM deals with second-generation ES issues whose focus is on creating and sustaining business benefits through the utilization of corporate ES.

This presents challenges for the education of IS students. In general, students are unprepared for the omnipresence of ES. We see graduate students getting their first job in ES projects, either in the industry or as consultants. Usually they start with limited ES knowledge but after a few years they end up as change agents in their companies, not because of their formal education or because of a specific role, but as a consequence of their "behind the scene" knowledge of the ES setup, its configuration and ES-based innovation. With these competences they become crucial to any business development project due to the fact that the adaptation of ES seems to be the barrier to any major change in today's businesses.

The purpose of this paper is to start the discussion on how these changes should be reflected in our IS curriculum, and how best to provide students with the required ESM competences for the future?

The pressure of ES on the curriculum became apparent towards the end of the 1990s. In Germany the first experiments with SAP in the classroom began years earlier, and Becerra-Fernandez, Murphy \& Simon (2000) argued that integrating ERP in the business school curriculum was necessary - and rewarding. Hawkins, Ramp \& Shackleton (2001) provide guidelines on how to integrate the tools into the IS'97 model curriculum, and Stewart, Rosemann \& Hawkings (1999) discuss the design of a collaborative IS curriculum aimed at applying ERP systems in practice.

Al-Mashari (2003) maps the ES research challenges and discusses several ways of integrating ERP in the IS curriculum. The path that many universities and business schools have chosen, including the Aarhus School of Business, is to collaborate with one of the major vendors through university alliances. This will usually provide the school with software, staff education and tools that enable the students to run ES.

This paper will investigate the challenges of integrating ES into the IS curriculum and beyond by projecting the second-generation ES challenges onto existing disciplines thus framing the new field of ESM.

In the following we will first discuss the present research on ES. Based on an analysis of the impact of ES in the subsequent section, we will outline our proposal for a second-generation ESM research framework. Finally we discuss the implications of this new research framework on the IS curriculum. The paper concludes by proposing four cornerstones for future ESM education. 


\section{Enterprise Systems}

Few IT innovations have had as much impact on business organizations in the past years as enterprise systems. ES are a standardized software package designed to integrate the data used throughout an entire organization (Davenport, 1998). According to Nah (2002) the American Production and Inventory Control Society (APICS) defines ES or ERP as "a method for the effective planning and controlling of all the resources needed to take, make, ship and account for customer orders in a manufacturing, distribution or service company". The APICS definition extends the concept of ES from an IT system towards a technology to manage and to organize the processes of an enterprise. It should be noted that there is no agreement on terms and definitions regarding ES. This is a rapidly evolving concept, and like Davenport (1998) we prefer to use the term Enterprise Systems to emphasize the generics of the concept rather than to use a term such as ERP, which would indicate a narrower scope. Moreover, we wish to focus on planning and coordination.

Many large enterprises have implemented ES and have now taken their next step on the ES journey. This journey is often described in terms of waves (Shank, Seddon \& Willcock, 2003). The first ES wave includes the acquisition, configuration and implementation along with resulting changes in the organization after going live with the system for the first time. The second wave includes making continuous improvements and maximizing the benefits from ES.

The ES have changed fundamentally over the last five years (Calloway, 2000), and companies are now taking advantage of new web-based technologies and advanced functions in order to establish an integrated extended enterprise (Davenport \& Brooks, 2004). This new generation ES is often referred to as ERP II systems (Bond, 2000).

Second wave ES projects are spurred on as a result of some of the questions managers are asking themselves after having gone through first wave ES projects. These include: How can we gain greater benefits from our ES investments? How can we manage and enhance our ES to continuously align the system with the strategy and structures of the organization? How will ES impact the business and create new work procedures (Kræmmergaard \& Koch, 2002)? This means that implementation issues are no longer the primary concern and that the focus has shifted to utilization, development and business value enhancement.

We have a good picture of the research into the first wave (Esteves \& Pastor, 2001). First wave ES implementations have been explored through case studies which have focused on for instance ES strategic options, how to avoid failures, how to identify issues of alignment, and business process reengineering issues. Only recently we have seen research aimed at ES beyond the cost-intensive implementation phase. However, the work we have seen on the actual application and impacts of ES has a clear message: These systems have the capability to transform a business, but only if the organization is able to integrate the activities - not only internally, but also across the external value chain (Marcus \& Tanis, 2003; Roos, Vitale \& Willcocks, 2003; Davenport, Harris \& Cantrell, 2004). This requires the enterprise system to be managed as an independent area in the organization to fully exploit its potential and secure that it continue to produce business benefits. We believe that this calls for a new management competence or function: Enterprise Systems Management which we elaborate on in the next section. 


\section{The emergence of Enterprise Systems Management}

After having implemented ES, organizations tend to refocus their attention towards issues regarding efficiency and effectiveness of the acquired systems (Rikhardsson, Kræmmergaard \& Møller, 2004). Enterprise Systems reside in a complex interplay with general management, and we need to consider the impact of ES on business as well as business impact on the enterprise systems usage. ES often constrain organizations in their business activities, ES enable and limit strategic options, and also ES have an impact on external business partners. ES can thus be a source of competitive advantage as well as being a business risk. ES management is therefore a broad field which includes a number of issues and challenges.

Below we have outlined six critical areas where management needs to monitor the overall business impact of ES.

1) Business strategy. ES have an impact on the strategic development of many organizations, and further inflict the way organizations collaborate across corporate borders.

2) Performance measurement, accounting and control. ES have an impact on how managers can account for and evaluate corporate performance, ensure that objectives are met and how plans are carried out.

3) Organization and culture. ES require another set of capabilities and competencies which will evolve into new ways of working and organizing.

4) ES technology. ES technology evolves rapidly. Each new release of software packages opens up new opportunities and brings on new constraint to the infrastructure of an enterprise.

5) Human resources. ES change the daily work of most employees, and the way they learn and develop new competencies with the system will be crucial.

6) Business processes. ES are a central component in most business process development projects, and managers should carefully consider the role of ES in the projects. ES sometimes become a barrier to development.

An ES research program is being established at the Aarhus School of Business. It is carried out by a consortium of researchers from various disciplines including informatics, accounting and organization. This consortium utilizes the synergy effects inherent in studying ES from these different perspectives, as the individual researchers will focus on different issues when gathering and analyzing empirical data. They contribute with different perspectives on ES management when formulating models, theories and management guidelines. This research forms the basis for challenging existing knowledge about ES and spurs on the formation of new inter-disciplinary models and theory of second-wave ES.

The overall aim of the ES research effort will be both academic and practical. Academic aims include refining various theoretical perspectives on ES systems as well as the further development of methodologies and tools for researching the application of these systems. Practical aims include developing and disseminating knowledge and experience to managers engaged in managing ES.

The research itself is based on three different perspectives that build on a series of joint empirical studies as well as $\mathrm{PhD}$ projects. We describe the three perspectives below in order to illustrate the facets of ESM. 


\subsection{Supply Chain integration and ES}

SCM (Supply Chain Management) is a critical issue in many of today's businesses. The challenge of SCM is to integrate and to coordinate activities across organizational boundaries in order to manage the entire supply chain as a whole. Various ES include new technologies for integrating the supply chain thus providing a platform for SCM: businesses can adopt the new functions offered by the new generation of ES thereby taking advantage of the technological innovations. Second wave ES represent a paradigm shift in systems architecture. These systems support not only networked information exchange but also process integration and collaboration, Collaborative Planning Forecasting and Replenishment (CPFR), Vendor Managed Inventories (VMI) and Supply Chain Event Management (SCEM).

The theoretical objective of this perspective is to establish a framework and methodology for designing effective business systems based on new enterprise systems architecture and supply chain configuration.

However, these technologies are not yet widespread, suggesting a gap between practice and the implied new business models. This perspective needs to explore the relationship between the ES architecture and the supply chain strategy. Potential issues include:

- Agile implementation, e.g. rapid implementation methods from ES vendors

- Modular extended enterprises, decentralized and autonomous supply networks

- Agent-based systems for planning and control in Extended Enterprises

- Application of generic process models, e.g. SCOR, SAP reference models

- Development and diffusion of exchange standards, e.g. ebXML or RosettaNet

- Process modeling techniques and collaborative systems design

- Process integration and an experimental design laboratory

\subsection{Accounting and ES}

Accounting is a central activity in any organization and can be seen as an important information system for internal and external stakeholders. The distinction between internal and external stakeholder information needs is reflected in the organization of accounting into management accounting which provides managers with decisionrelevant information and financial accounting which provides external stakeholders with information.

The advent of enterprise systems entails for instance new IT architecture, support of business processes across organizational, temporal and regional boundaries, new forms of organizing, new accountability practices, new partnerships, and new forms of communication. These changes have an impact on accounting by changing processes, automating registration tasks, improving business analyses, extending spans of control, enabling more delegation, creating new business risks and changing the role of accounting departments, among other things.

ES managers need to consider these impacts including:

- Budgeting and controlling issues: How ES can improve budgeting processes, follow ups, budget analysis and control by means of for example real time budgeting, automatic follow-up and electronic scorecards.

- Accounting system security: How ES create new risks such as hacking and IT fraud that have to be dealt with 
- Cost accounting: How ES can enable more accurate cost accounting by improving cost allocation, enabling better costs structures, and making costrevenue links more explicit.

- Management reporting: How ES can improve management reporting though business performance applications, OLAP technologies and innovative reporting formats.

- Financial reporting: How ES can increase transparency by improving external reporting by e.g. online access to financial data by analyses, real time financial reporting and continuous shareholder information.

\subsection{Managing and organizing of ES}

Most organizations today are totally dependent on their ES and would quickly cease to function should the technology that underpins them ever grind to a halt. This implies that organizations have to manage and organize their ES continuously. In many organizations, the responsibility for the ES traditionally lies within the IS function, even though the role of IT has expanded significantly over the years to the extent that it now often shapes business strategy. At the same time it is difficult to achieve user and business manager involvement in ES activities, despite the fact that findings from research show that user and business manager involvement is critical for the success of ES.

The implementation and use of ES, both in the first and second waves, are a combined process of radical change and continuous organizational learning. The implementation of an ES can be understood as a directed change which can transform the organization radically. However, when using the implemented system continuous organizational learning takes place resulting in continuous changes. Additionally, new modules and functionalities are continuously added to the system during its lifecycle, resulting in organizational learning and change - or put in another way, the implementation of an ES was just the first step leading to many other steps. ES managers need to consider these challenges, including:

- Management and user involvement: How is business manager and user involvement achieved in ES-related activities?

- Alignment: How to ensure that the ES, the business strategy, and the organizational structures and culture are constantly aligned?

- Change and learning: How is learning sustained in the organization? How can new organizational changes constantly be introduced to the organization? How can we learn from the users of the ES?

- Competences: Which managerial competences are required for the ES manager and the ES consultant?

- Organizing: How are the activities around the ES organized? How to structure the ES department and collaborate with external consultants?

\subsection{Framing Enterprise Systems Management}

The above three perspectives illustrate the complexity facing the ES manager. Enterprise Systems Management deals with the management processes involved in acquiring, configuring, implementing and using Enterprise Systems effectively. This is not fundamentally different from traditional ES research but here we emphasize the effective use of the systems. 
Consequently the ES manager must be an architect, or be able to assist topmanagement in innovating business concepts and models, designing the business architecture and engineering processes across the entire organization, and build relations to the customers and suppliers. This also implies that the ES manager must reconcile the different business functions, motivate and sustain new processes, and "sell" the capabilities of ES.

Today there are many areas of IS which consider these issues. Examples are IT strategy, IT governance, IS evaluation and more. Since second-wave ES projects are not only embedded in an organization, but are often centered around and driven by the ES manager, we propose ESM as an explicit field of study.

\section{Discussion of educational impact}

In the traditional fields like operations management, logistics and accounting, ES are not necessarily seen as enablers of this transformation. For instance in logistics we usually introduce the students to the concepts of forecasting and MRP as generic concepts to understand planning and control. IS strategy deals with IT impact in general but we have not yet seen any systematic models dealing with the continuous development of business concepts and models driven by new features in standard ES.

As we have seen, teaching the students to use ES is not new anymore. Then what are the critical issues in ESM education? We see four important challenges:

The first challenge regards the transformation of a technically oriented IS curriculum towards dealing with business issues and architecture. If we assume that one of the future roles of the students is that os a business architect, what are the tools required of an architect?

In the past we have provided the students with engineering tools, programming and other technical skills. In future, we will have to provide our student with modeling and design competences, and perhaps even more important with creative problemsolving skills. Furthermore, students have to explore how ES relate to various business functions such as marketing, accounting, finance and general management.

This leads to the second interesting challenge: Who will provide the new concepts and the business models? The ES vendors provide reference models or "best practice" in their systems, but do these models have their origin in research or in innovative industrial practices? As educators we need to teach the students how to identify the source of these models, and on their own find ways to incorporate and integrate these new concepts based on the contingencies of an existing company. To some extent, this requires the development of new partnerships between ES vendors and the education sector where the ES vendors provide access to systems, documentation, process dictionaries etc.

The third challenge is that we, as educators, need to question the idea of ES as backoffice systems. In most mature ES organizations they are competence center based with internal ES consultants bridging the gap between IT and business functions. Those would be likely positions for our graduate students, and we must therefore define and develop the new competences to fulfill this role - including consultancy skills, conflict management and communication skills.

A fourth challenge relates to the inter-organizational nature of ES. Many of today's integration projects involve collaboration complexity well above EDI-based exchange of information. As educators we need to enable the students to navigate complex 
lateral projects and to deal with cross-company issues like trust, legislation, politics etc. Those would be issues that are beyond any normal curriculum.

\begin{tabular}{|l|l|l|}
\hline Challenge & Approach & References \\
\hline $\begin{array}{l}\text { To identify new concepts } \\
\text { and business models }\end{array}$ & $\begin{array}{l}\text { Case studies in innovative } \\
\text { organizations }\end{array}$ & $\begin{array}{l}\text { Hørlück et al. (2001) } \\
\text { ASCET (2001-2004) }\end{array}$ \\
\hline $\begin{array}{l}\text { To design business } \\
\text { architecture }\end{array}$ & Business process modeling & $\begin{array}{l}\text { Scheer (1998) } \\
\text { Curran (1999) } \\
\text { Stewart \& Rosemann } \\
\text { (2001) }\end{array}$ \\
\hline $\begin{array}{l}\text { To develop new } \\
\text { competencies }\end{array}$ & Problem-based learning & $\begin{array}{l}\text { Kjærsdam (1994) } \\
\text { Kolmos (1996) } \\
\text { Stewart \& Gable (1999) }\end{array}$ \\
\hline $\begin{array}{l}\text { To organize inter- (and } \\
\text { intra) organizational } \\
\text { collaboration }\end{array}$ & Games, role-play & $\begin{array}{l}\text { Kaminsky \& Simchi-Levi } \\
(1998)\end{array}$ \\
& & $\begin{array}{l}\text { Riis, Smeds \& Landeghem } \\
\text { (2000) } \\
\text { Kaltoft et al. (2003) }\end{array}$ \\
\hline
\end{tabular}

Table 1. Educational cornerstones of ESM

In table 1 we have outlined the four challenges and some potential approaches to respond to these challenges.

Students need to be able to identify and understand new concepts and business models. These skills could be achieved by analyzing innovative organizations' use of IT. One of the projects we have been involved in provided a repository of crossdisciplinary teaching cases (Hørlück et al. 2001). Another comprehensive source of illustrative cases is the Achieving Supply Chain Excellence through Technology (ASCET) project. ASCET has produced a number of cutting-edge cases from firms relying heavily on information technology.

One of the approaches to dealing with business architecture is to use business processes as a perspective. This implies teaching the students to analyze, model and design business processes. One of the successful tools is the ARIS framework (Scheer, 1998) which is consistent with SAP reference models (Curran \& Ladd, 1999). This usually involves traditional approaches where students get the opportunity to use ES system functionalities in various contexts (Rosemann \& Stewart, 2001).

New competence relates to practice and may be difficult for student to obtain. We have successfully applied problem-based learning as a tool to teach students to apply business concepts in real-life projects. Aalborg University has pioneer problem-based learning (Kjærsdam, 1994; Kolmos 1996) and it is similar to the framework that Stewart and Gable (1999) propose as an instrument to develop research and consultancy skills in post-graduate students.

To be able to organize inter- and intra-organizational collaboration the student needs to develop competencies way beyond any curriculum. However, there are feasible approaches. One of the best known examples is the MIT Beergame developed by Jay Forrester (Kaminsky \& Simchi-Levi, 1998). The Beergame is an example of how to use game-playing as a tool to gain insight into a complex situation. Game playing is a researchable phenomenon (Riis, Smeds \& Van Landeghem, 2000). An example of 
developing strategic supplier collaborations in inter-organizational environments through a participating role game can be found in Kaltoft et al. (2003).

We do not see the above four issues as a comprehensive list; rather we propose them as cornerstones of ESM. However, this subject needs to be researched further.

\section{Conclusions}

As a main contribution, this paper has outlined four emergent teaching challenges in Enterprise Systems Management education:

- To identify new concepts and business models

- To design business architecture

- To develop new competencies

- To organize inter- and intra organizational collaboration

We have proposed approaches to deal with these challenges and given references as examples. The approaches are not new, and some of them have already been widely applied in IS/OM education, but our main claim is that we need to integrate all four cornerstones in the IS curriculum to be able to teach and educate the Enterprise Systems managers of the future.

At the Aarhus School of Business we introduce the students to an ES system and ES concept from the very first day of their study. The general idea is to relate the concepts in the proceeding courses in operations management, accounting, organization theory etc. to the business models and workflows in the ES. By applying the cornerstones throughout their education, we hope to provide the students with an integrated view on IS and business.

\section{References}

Al-Mashari, M. (2003). Enterprise resource planning (ERP systems: A research agenda. Industrial Management and Data Systems, 103(1), 22-27.

Becerra-Fernandez, I., Murphy, K. E., \& Simon, S. J. (2000). Integrating ERP in the business school curriculum. Communication of the ACM, 43(4), 39-41.

Bond, B., Genovese, Y., Miklovic, D., Wood, N., Zrimsek, B., \& Rayner, N. (2000). ERP is dead - long live ERP ii (No. Strategic Planning SPA-12-0420): GartnerGroup.

Callaway, E. (2000). ERP - the next generation: ERP is web enabled for e-business. South Carolina: Computer Technology Research Corporation.

Curran, T. A., \& Ladd, A. (1999). Sap R/3 business blueprint: Understanding enterprise supply chain management (2nd edition): Prentice Hall PTR.

Davenport, T. H. (1998). Putting the enterprise into the enterprise system. Harvard Business Review, July/August, 121-131.

Davenport, T. H., \& Brooks, J. D. (2004). Enterprise systems and the supply chain. Journal of Enterprise Information management, 17(1), 8-19.

Davenport, T. H., Harris, J. G., \& Cantrell, S. (2004). Enterprise systems and ongoing process change. Business Process Management Journal, 10(1), 16-26.

Esteves, J., \& Pastor, J. (2001). Enterprise resource planning systems research: An annotated bibliography. Communications of the AIS, 7(8), 1-52. 
Hawking, P., Ramp, A., \& Shackleton, P. (2001). IS'97 model curriculum and enterprise resource planning systems. Business Process Management Journal, $7(3)$.

Hørlück, J., Kræmmergaard, P., Rask, M., \& Rose, J. (Eds.). (2001). Organizing for networked information technologies: Cases in process integration and transformation: Aalborg University Press and PITNIT.

Kaltoft, R., Nielsen, J. S., Møller, C., \& Kræmmergaard, P. (2003). Building strategic supplier collaboration through gaming. Paper presented at the 7th International Workshop on Experimental Interactive Learning Industrial Management, Aalborg.

Kaminsky, P., \& Simchi-Levi, D. (1998). A new computerized beer game: A tool for teaching the value of integrated supply chain management. Global supply chain and technology management (Vol. 1, pp. 216-225).

Kjærsdam, F. (1994). The Aalborg experiment, project - innovation in university education. Aalborg: Aalborg University Press.

Klaus, H., Rosemann, M., \& Gable, G. G. (2000). What is ERP? Information Systems Frontiers, 2(2), 141-162.

Kolmos, A. (1996). Reflections on project work and problem-based learning. European Journal of Engineering Education, 21(2), 141-148.

Kræmmergaard, P., \& Koch, C. (2002). Managing ERP after going-live. Paper presented at the Proceedings of the 9th International Conference European Operations Management Association, Copenhagen.

Markus, M. L., Petrie, D., \& Axline, S. (2003). Continuity versus discontinuity: Weighing the future for ERP packages. In G. Shanks, P. Seddon \& L. Willcocks (Eds.), Second-wave enterprise resource planning systems implementing for effectiveness: Cambridge University Press.

Markus, M. L., \& Tanis, C. (2000). The enterprise systems experience - from adoption to success. In R. W. Zmud (Ed.), Framing the domains of IT research: Glimpsing the future through the past (pp. 173-207). Cincinnati, OH: Pinnaflex Educational Resources, Inc.

Murphy, T. (Ed.). (1999-2004). Achieving supply chain excellence through technology: Montgomery Research.

Møller, C. (2004). ERP II - a conceptual framework for the next-generation enterprise systems? To appear in Journal of Enterprise Information Management.

Møller, C., Kræmmergaard, P., \& Rotbøl, M. (2003). Virksomhedssystemer i Danmark 2003 - en analyse af de 500 største danske virksomheders ERP systemer (IFI working paper series no. 126 No. ISSN no. 1398-067X). Aarhus: Department of Information Science.

Nah, F. F.-H. (Ed.). (2002). Enterprise resource planning solutions and management: IRM Press.

Riis, J. O., Smeds, R., \& Landeghem, R. V. (2000). Games in operations management: Kluwer.

Rikhardsson, P., Kræmmergaard, P., \& Møller, C. (2004). ERP enterprise resource planning - danske erfaringer med implementering og udnyttelse af ERP systemer: Børsen Bøger.

Rosemann, M., \& Stewart, G. (2001). Process modeling - a teaching approach for developing generic skills in IT students. Paper presented at the Proceedings of the 7th Americas Conference on Information Systems - AMCIS 2001, Boston, US. 
Ross, J., Vitale, M. R., \& Willcocks, L. P. (2003). The continuing ERP revolution: Sustainable lessons, new modes of delivery. In G. Shanks, P. Seddon \& L. Willcocks (Eds.), Second-wave enterprise resource planning systems implementing for effectiveness: Cambridge University Press.

Scheer, A.-W. (1998). Aris - business process frameworks: Springer-Verlag Berlin and Heidelberg GmbH \& Co. KG.

Shanks, G., Seddon, P. B., \& Willcocks, L. P. (Eds.). (2003). Second-wave enterprise resource planning systems: Implementing for effectiveness: Cambridge University Press.

Stewart, G., \& Gable, G. (1999). Applying the case study and action research methods to post-graduate studies of enterprise processing system implementations. Paper presented at the Maximizing the Synergy between Teaching, Research and Business.

Stewart, G., Rosemann, M., \& Hawking, P. (2000). Collaborative ERP curriculum developing using industry process models. Paper presented at the Proceedings of the 2000 Americas Conference on Information Systems.

Wortmann, J. C. (1998). Evolution of ERP systems. In U. S. Bititchi \& A. S. Carrie (Eds.), Strategic management of the manufacturing value chain: Kluwer Academic Publishers. 


\section{Working Papers from Informatics Research Group}

I-2005-03 Charles Møller, Pernille Kræmmergaard \& Pall Rikhardsson: The Emergence of Enterprise Systems Management - A Challenge to the IS Curriculum.

I-2005-02 Pernille Kræmmergaard \& Jeremy Rose: Managing the ERP implemention journey - change in discourse from classical IT project to technology-driven organisational change initiative.

WP 05-1 Tina Blegind Jensen: Nurses’ Perception of an ERP Implementation Process - Based on a Means-End Chain Approach. 
ISBN 87-7882-084-7

Department of Accounting, Finance and Logistics

Aarhus School of Business

Fuglesangs Allé 4

DK-8210 Aarhus V - Denmark

Tel. +4589486688

Fax +4586150188

www.asb.dk 